\title{
Gas Isotopes Tracing: an Important Tool for Hydrocarbons Exploration
}

\author{
A. Prinzhofer ${ }^{1}$ and A. Battani ${ }^{1}$ \\ 1 Institut français du pétrole, 1 et 4, avenue de Bois-Préau, 92852 Rueil-Malmaison Cedex - France \\ e-mail: alain.prinzhofer@ifp.fr - anne.battani@ifp.fr
}

\begin{abstract}
Résumé - Les isotopes du gaz utilisés comme traceurs : un outil important pour l'exploration des hydrocarbures - Le gaz naturel peut être considéré aujourd'hui à la fois comme un traceur fiable pour la connaissance des hydrocarbures liquides qui peuvent lui être associés, et comme un enjeu économique en lui même. La mesure isotopique combinée des isotopes stables et des gaz rares donne des contraintes majeures pour reconstruire l'histoire géologique des hydrocarbures, depuis leur genèse jusqu'à leur accumulation. Des progrès récents dans la mesure des isotopes stables du carbone du gaz naturel (du méthane au butane et du dioxyde de carbone), liés principalement à l'utilisation de GC-C-IRMS (Gas Chromatograph-Combustion-Isotopic ratios mass spectrometer) ont permis de retracer de nombreux processus physico-chimiques qui affectent le gaz naturel, au lieu d'utiliser ces signatures comme de simples empreintes digitales d'origines, comme c'était l'usage auparavant. Ces reconstructions fournissent des informations capitales à la fois sur leur origine et sur l'évolution dynamique des fluides hydrocarbures entre la roche mère et l'accumulation dans les réservoirs. L'association de cette méthodologie avec l'utilisation d'autre traceurs naturels augmente notre connaissance de l'histoire des hydrocarbures dans les bassins sédimentaires. Entre autres méthodologies potentielles, les isotopes des gaz rares peuvent apparaître comme l'ultime outil de diagnostic, leur totale inertie chimique nous permettant de les utiliser tant comme des traceurs fiables de sources, que comme des indicateurs quantitatifs de processus physiques (état des phases, migration et fuites au travers des formations géologiques). Qui plus est, comme certains isotopes $\left({ }^{4} \mathrm{He},{ }^{40} \mathrm{Ar}\right.$ par exemple) sont produit par radioactivité naturelle, il représentent des horloges géologiques, donnant accès à la quantification des temps de résidence des hydrocarbures dans les réservoirs. Plusieurs applications nouvelles sont présentées dans cet article, associant les isotopes stables avec ceux des gaz rares : une nouvelle méthode permettant de distinguer l'origine bactérienne ou thermogénique du gaz, et la caractérisation de paramètres en relation avec la genèse du gaz thermogénique (craquage primaire ou craquage secondaire, degré d'ouverture du système, relations entre les signatures isotopiques et la biodégradation). Enfin, nous présentons une tentative de quantification de la proportion d'hydrocarbures ayant fui hors d'un réservoir, et des valeurs relatives des temps de résidence des hydrocarbures dans un système de réservoirs hétérogènes.
\end{abstract}

Abstract - Gas Isotopes Tracing: an Important Tool for Hydrocarbons Exploration-Gas may be considered today both as a reliable tracer for the understanding of associated liquid hydrocarbons and as an economic target. Isotopic measurements of stables isotopes and noble gases give important clues to reconstruct the geological history of hydrocarbons from their generation to their accumulation. Recent analytical advances in carbon isotopes of natural gases (methane to butane and carbon dioxide) due mainly to the development of GC-C-IRMS (Gas Chromatograph-Combustion-Isotopic ratios mass spectrometer) have allowed to reconstruct some of the physico-chemical processes which affect natural gas chemical signatures, instead of using these signatures as simple fingerprinting of origins as it was the 
case some time ago. These reconstructions provide important information on both the origins and the dynamic behavior of hydrocarbon fluids between the source rocks and the accumulations in reservoirs. Correlating this methodology with other natural tracers increases the understanding of hydrocarbon history in sedimentary basins. Among other new potential methodologies, noble gas coupled to stable isotopes are the new frontier tool, as their chemical inertia enables their use as precise tracers of sources and of associated physical processes (state of the phases, migration and leakage). Moreover, because some isotopes $\left({ }^{4} \mathrm{He},{ }^{40} \mathrm{Ar}\right.$ for example) are produced by natural radioactivity, they may very well represent geological "clocks", giving potentially a quantification of the residence times of hydrocarbons in a reservoir. Several new applications of this association of stable isotopes and noble gases are presented in this paper: a new way for distinguishing bacterial and thermogenic gas origins, and the characterization of the parameters related to the genesis of thermogenic gas (primary versus secondary cracking, openness of the system, relations between gas isotope signatures and biodegradation). At last is presented a tentative quantification of the proportion of hydrocarbon gases leaked from a reservoir, and a quantitative relative residence times of hydrocarbons in heterogeneous reservoirs.

\section{INTRODUCTION}

The exploration of natural gas became during the last decade as important as the liquid hydrocarbons quest. Although a large part of the R\&D work performed for petroleum exploration could be used for the understanding of gas accumulations, it rapidly appeared that some specific problems were to be addressed specifically for the understanding of gas history. Therefore, some geochemical tools could be especially valuable for gas characterization. Natural gas is a relatively simple mixture when compared to oil, as it contains fewer gas molecules in major proportions: the hydrocarbon part consists of methane, ethane, propane, normal-butane and isobutane (the isomers of pentane are already highly fractionated between the liquid and gas phase at a separator, and cannot be generally used as reliable data). The three most common nonhydrocarbon gases are $\mathrm{CO}_{2}, \mathrm{~N}_{2}$ and $\mathrm{H}_{2} \mathrm{~S}$. Their concentration ranges from 0 to almost $100 \%$, and they are considered a hazard in gas exploration. Among the other molecules in trace amounts, the whole family of noble gases ( $\mathrm{He}, \mathrm{Ne}, \mathrm{Ar}, \mathrm{Kr}, \mathrm{Xe}$ and $\mathrm{Rn}$ ) is always present in natural gas, and other compounds as hydrogen or mercury have been sometimes detected. Apart from the chemical proportions of these different molecules, the use of isotopic ratios has been rightfully adapted to oil and gas interpretations. Part of the reason is that of the GC-C-IRMS technique (coupling of a gas chromatograph with a mass spectrometer devoted to stable isotopes measurements) changed drastically the amount and quality of data obtainable from gas samples. Ten years ago, the whole analysis of carbon isotopes of one gas sample took several days, whereas it is now possible on a routine basis in half an hour. Moreover, this online technique allows to analyze much smaller volumes, rendering possible today the analysis of the carbon isotopic signature of an hydrocarbon molecule with an abundance as low as $100 \mathrm{ppm}$, which was not feasible before. Likewise, very recent technological development of the same kind of online analysis for the hydrogen isotope composition of hydrocarbons will probably give a new geochemical leap for the study of hydrocarbon gases in the next decade. The implementation of noble gases and respective isotope studies are still in a process of new development and research for the purpose of hydrocarbon exploration. However, the wide knowledge of the geochemical behavior of these natural tracers, associated with some pioneer work in oil and gas characterization (Zartmann et al., 1961; Bosch and Mazor, 1988; Ballentine and O’Nions, 1994; Ballentine and Sherwood-Lollar, 2002) indicates that their generalized use is probably of paramount importance for a better understanding of petroleum system.

The reconstruction of the history of a petroleum system involves several steps. Some of them are already well developed with the association of organic geochemistry and basin modeling. However, several other aspects still need a better quantitative estimate: reservoir continuity, distance and rate of migration of the hydrocarbons from the source rocks to the reservoir, and from the petroleum system to the atmosphere, age and residence time of accumulated hydrocarbons, origins and sources of natural gas, prediction of the risk of nonhydrocarbon gases as $\mathrm{CO}_{2}$ and $\mathrm{N}_{2}$. A more accurate attention given to the chemical and isotopic signatures of natural gases (hydrocarbons and nonhydrocarbons) may have other industrial implications, for example in the field of $\mathrm{CO}_{2}$ sequestration, or for the estimation of potential productions of helium as a by-product of gas accumulations. We present in this paper some examples of these new methodologies for several case studies, highlighting the performances for the prediction of quality/volume during exploration, by using stable isotopes associated with noble gas isotopes.

Stable isotopes are natural tracers related to the source signature of gas samples, and fractionated by the chemical and physical processes which affect in a slightly different way the different isotopes of a same chemical compound, with the general rule that lighter isotopes present a higher chemical reactivity, and are more mobile than the heavier 
ones. Their actual isotopic signature is therefore a superposition of a lot of chemical and physical informations, rendering sometimes difficult their interpretation.

On the other hand, noble gas molecules have the unique property to be absolutely inert chemically, and to allow the tracing of sources and of physical processes of segregation during the history of a petroleum system without any interference with chemical processes (Ballentine and O'Nions, 1994). The second important advantage of noble gases is that they may be classified in two main groups. Some of them are fossil, created during the formation of the solar system, with their main reservoir being the atmosphere, and completely conservative as they are not chemically reactive. These molecules enter hydrocarbon fluids through their solubilization in water in the zones of water recharge, and are then exchanged and fractionated between crustal fluids (gas, oil and water). The other group comprises species produced through natural nuclear reactions, and may accumulate through time, offering potential natural clocks inside the crustal fluids. More in-depth will be discussed in Chapter 4 about radiogenic/nucleogenic production. Interestingly, their large range of molecular mass (from 3 for helium to 136 for xenon) gives a large spectrum of physical properties (solubilities between phases, diffusion coefficients, etc.). These various properties, well constrained through numerous academic studies, may and are potentially used quantitatively for petroleum system evaluation.

Among the numerous applications which are being developed associating carbon isotopes and noble gas geochemistry, one may quote:

- The source of nonhydrocarbon gases like $\mathrm{CO}_{2}$ and $\mathrm{N}_{2}$. Indeed, the stable isotopes of these two compounds generally do not give a unique answer for their origins, whereas the isotopic signature of helium ${ }^{3} \mathrm{He} /{ }^{4} \mathrm{He}$ indicates the possible proportion of these molecules coming from the mantle, versus those accumulated directly from a continental crust (Battani, 1999; Battani et al., 2000).

- The distinction between a bacterial and a thermogenic origin of natural gas may be confirmed by a completely novel methodology using the apparent production ratio of two radiogenic isotopes of noble gases, ${ }^{4} \mathrm{He}$ and ${ }^{40} \mathrm{Ar}$.

- Segregation during the migration of natural gas may be monitored through the carbon isotopes of methane (Prinzhofer and Pernaton, 1997; Prinzhofer et al., 2000a). However, these signatures are strongly dependent upon the genesis of the gas (bacterial versus thermogenic) and on the maturity of the source, obscuring the part of the fractionation due to gas migration through porous rocks. On the contrary, because of their inertia, isotopic and chemical ratios of noble gases are fractionated only by physical processes, i.e. in this case the interaction between fluids and fractionation during diffusion. The projection of such data in migration maps at the basin scale or at the reservoir scale are coherent with stable isotopes but also much less "noisy".

- As the fossil isotopes of noble gases enter the gas phase from the water phase, their absolute and relative concentrations are directly linked to the amount of water equilibrated with the gas accumulation. This direct estimate of the importance of water contact with hydrocarbons has obvious direct implications for any estimation of a risk of biodegradation or hydrodynamism in a petroleum reservoir.

- The amount of radiogenic noble gases is linked to several key parameters, the amount of parent isotope, the efficiency of accumulation in the hydrocarbon phase and the time. This last parameter is extremely important, as it allows to test for the first time direct chronological information for hydrocarbons accumulations.

- Finally, apart from the application to petroleum exploration, and because of their chemical inertia, noble gases may be used to monitor multi-layered or compartmentalized fields production, the relative proportions produced from each block of the field versus time. This kind of new geochemical monitoring of a multi-play gas field may give a precise and less expensive information about the evolution of the production.

We shall now provide more details of some examples of these different applications.

\section{BACTERIAL METHANOGENESIS VERSUS THERMAL CRACKING: CHARACTERIZATION OF GAS ORIGINS AND NEW AMBIGUITIES}

The origins of methanogenesis in hydrocarbon reservoirs have been extensively studied through the last decades (Colombo et al., 1970; Stahl, 1977; Bernard et al., 1977; Schoell, 1980, 1983; Galimov, 1988; Faber et al., 1992; Prinzhofer and Huc, 1995; Prinzhofer et al., 2000a; Prinzhofer et al., 2000b). Even if some unconventional methane generation has been noted to occur through marginal inorganic processes (Charlou and Donval, 1993; Charlou et al., 1998; Guo et al., 1997; Wang et al., 1997; Szatmari, 1989), the main origins of hydrocarbons are organic. They are traditionally subdivided in two classes of processes: one process occurs during the thermal degradation of organic matter, and is associated with the generation of large amounts of heavier gas molecules and liquid hydrocarbons; the other generation process occurs through bacterial methanogenesis with insignificant amounts of other hydrocarbon molecules. The distinction between these two genetic processes is still subject to discussion in several case studies. Bacterial contamination is an important issue when characterizing the gas origin and migration with stable isotopes, as the correct interpretation of the data is sometimes delicate: in the last two decades, it was deemed easy to 
distinguish gas generated by thermal cracking from methanogenesis using the carbon and hydrogen isotopes (Bernard et al., 1977; Schoell, 1983: Faber et al., 1992). These authors demonstrated that bacterial genesis of gas gave gas enriched in methane, isotopically light compared to a thermal generation. Several diagrams were proposed to illustrate the distinction between a bacterial field of generation and a thermogenic one (in Figure 1 is represented the first of these diagrams, from Bernard et al., 1977). Gases with intermediate compositions were interpreted by these authors as mixes between a bacterial and a thermogenic endmember. The supplementary information obtained with the hydrogen isotopic ratio of methane enables to add a characterization of the biogenic path which occurred, i.e. the fermentation of acetates or the reduction of $\mathrm{CO}_{2}$ (Schoell, 1983; Faber et al., 1992).

However, recent studies have shown that bacterial oxidation of bacterial gas may give a residual gas showing a thermogenic signature, whereas diffusive processes during migration may give a bacterial signature to a thermogenic gas (Prinzhofer and Pernaton, 1997). In Figure 2 are plotted the results of several migration experiments (where the gas migration occurs by diffusion, through a slice of shale or sandstone, saturated or not with water) where it is possible to obtain a purely bacterial signature for methane, or a signature supposedly corresponding to a mixing, when the gas is actually a purely thermogenic gas. This indicates that

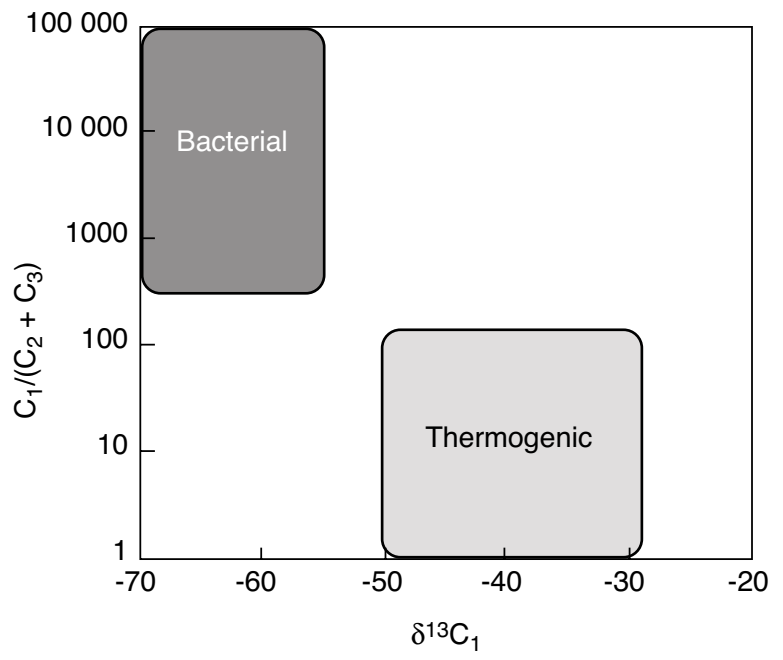

Figure 1

Distinction of the two different organic geneses of natural gas (bacterial versus thermogenic). This distinction is based on the dryness of bacterial gas, and on the fact that the carbon isotopic ratio of methane is lighter for bacterial gas than for thermogenic gas. From Bernard et al. (1977), modified.

Figure 1 represents the genetic signature of the gases, but that post-genetic processes as chemical and bacterial alteration, or physical migration may change drastically these original fingerprints.

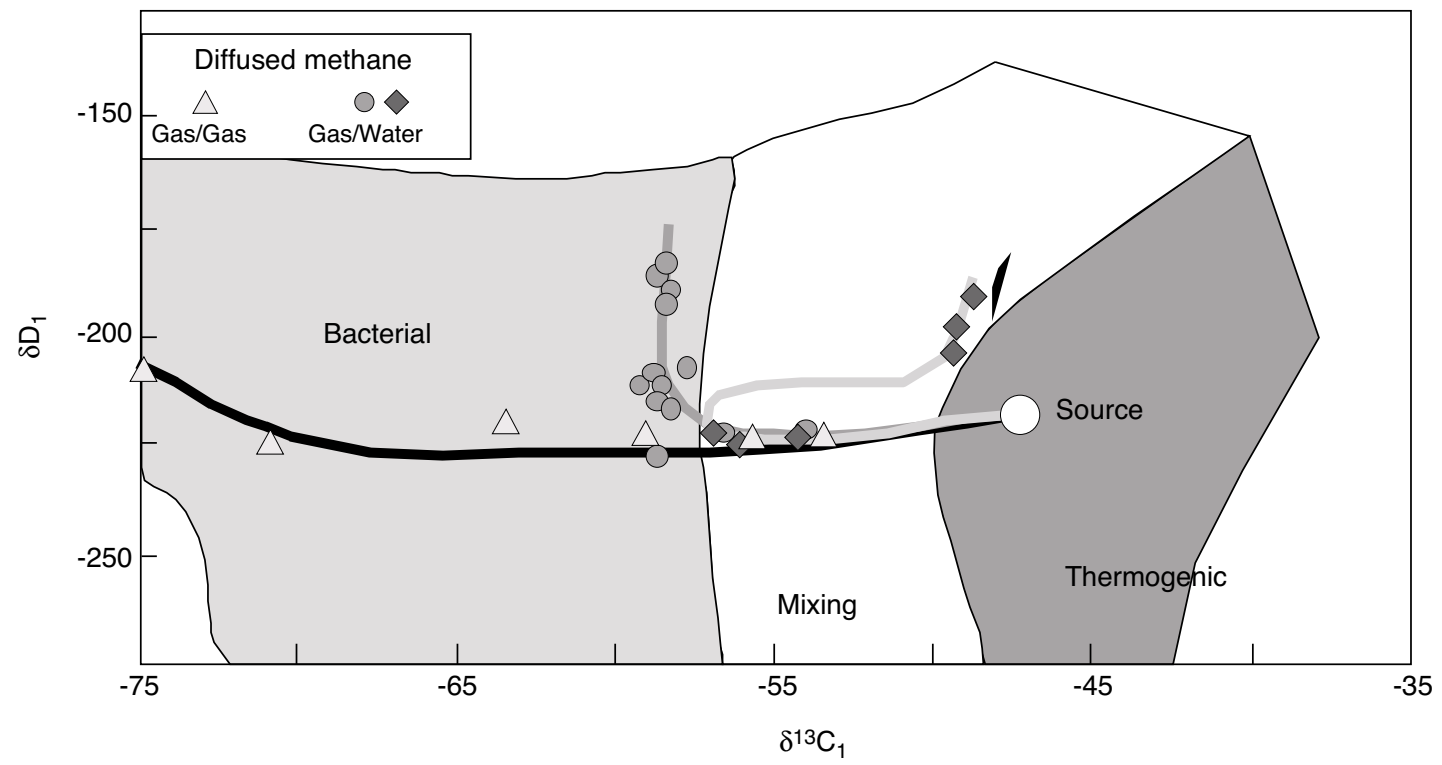

Figure 2

Experimental results of methane migration through shales, saturated or not with water. The migration occurs by water solubilization/ diffusion, and the data are presented in a hydrogen versus carbon isotopic ratios. The ranges of genetic signatures corresponding to bacterial and thermogenic methane are also represented (from Faber et al., 1992), showing that a purely thermogenic methane may present a bacterial signature (or a mixed one), due to its migration through a porous rock. The series of data correspond to a migration through water saturated shales, but with different petrophysical properties. From Prinzhofer and Pernaton (1997), modified. 


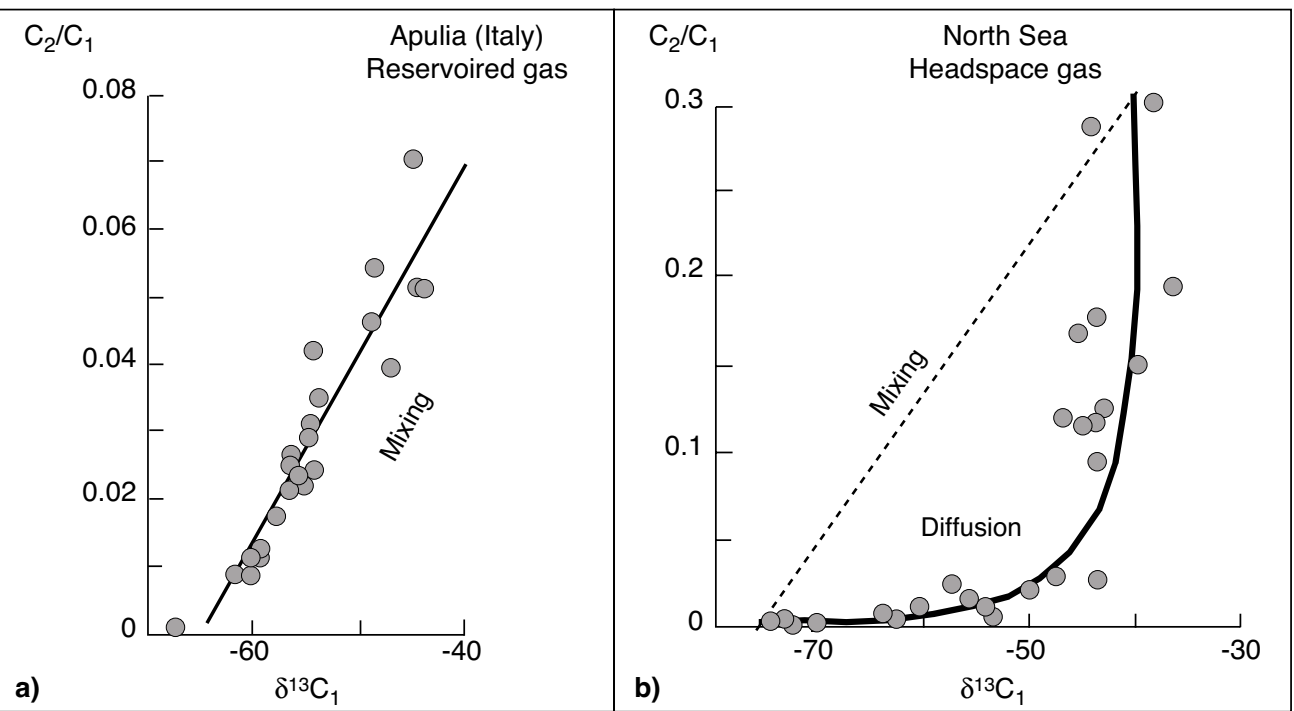

Figure 3

Two examples of gas series in the mixing diagram $\mathrm{C}_{2} / \mathrm{C}_{1}$ versus $\delta^{13} \mathrm{C}$ of methane. a) gas data from Apulia (Ricchiuto and Schoell, 1988), showing a straight line interpreted as a mixture between a thermogenic and a bacterial end-member. b) gases from headspace gases collected during a drilling of a North Sea field. The curved trend is incompatible with a mixing between two end-members, and is interpreted as the result of a chemical and isotopic fractionation during the leakage of a thermogenic fluid accumulated in a reservoir located below. From Prinzhofer and Pernaton (1997), modified.

In some cases, it is then possible to distinguish these processes using the principle of the mixing diagrams. Prinzhofer and Pernaton (1997) nonetheless demonstrated that for gases with isotopically light methane (supposedly contaminated by bacterial activity), a mixing process could not explain the observed geochemical trends, and that a fractionation linked to post-genetic processes as migration and adsorption/desorption needed to be invoked. Furthermore, in some other case studies, even with mixing diagrams, the obtained results remained ambiguous. Figure 3 shows data from Apulia (Italy), which are consistent with a mixing scenario between bacterial and thermogenic end-members, and data from headspace gases incompatible with a mixing, and interpreted as due to a fractionation during leakage of the gas out of the reservoir.

The authors have developed very recently a totally independent way of distinguishing these two gas origins (Prinzhofer, 2001), using the ratios of two radiogenic noble gases, ${ }^{4} \mathrm{He}$ and ${ }^{40} \mathrm{Ar} *$ (radiogenic part of total ${ }^{40} \mathrm{Ar}$ ), as they are not affected by chemical secondary processes. Additionnally, physical processes should not fractionate helium and argon in the range of the observed variations. As these molecules are generated from the mineral network, their ratio in a gas phase depends only on the production ratio in the rocks and the physical fractionation during their transfer from the solid to the gas phase. As helium diffuses more easily than argon, the ratio ${ }^{4} \mathrm{He} /{ }^{40} \mathrm{Ar} *$ is expected higher in bacterial gas, as the generation temperature is low enough to forbid the major part of argon to leave the solid (Elliot et al., 1993). On the contrary, the higher generation temperatures of thermogenic gas promote a very effective transfer of both molecules, and the ${ }^{4} \mathrm{He} /{ }^{40} \mathrm{Ar} *$ ratio measured in these gases is always close to the average crustal production ratio. Several well-documented natural examples, with unambiguous origins of the gases, validate this new way of characterizing gas generation (Fig.4). However, it becomes clear with such examples that the gap supposedly existing between the bacterial generation and the thermal one diminishes. The estimation of newly discovered hidden biomass, the possibility for some bacteria to live in extreme thermal conditions pushes the limits of bacterial methanogenesis probably in the range of the beginning of the thermal degradation of organic matter. The ancient observation of an "early thermogenic gas" which would be dry and non associated with oils may be reconciled with new observations concerning the behavior of reduced carbon cycles in a sedimentary column.

\section{ESTIMATION OF THE MATURITY OF A GAS: PRIMARY VERSUS SECONDARY CRACKING. POSSIBLE SECONDARY BIODEGRADATION}

As the proportions and isotope ratios of methane are highly subjected to post-genetic processes, a new attempt for characterizing the maturity of the gas was done using the 

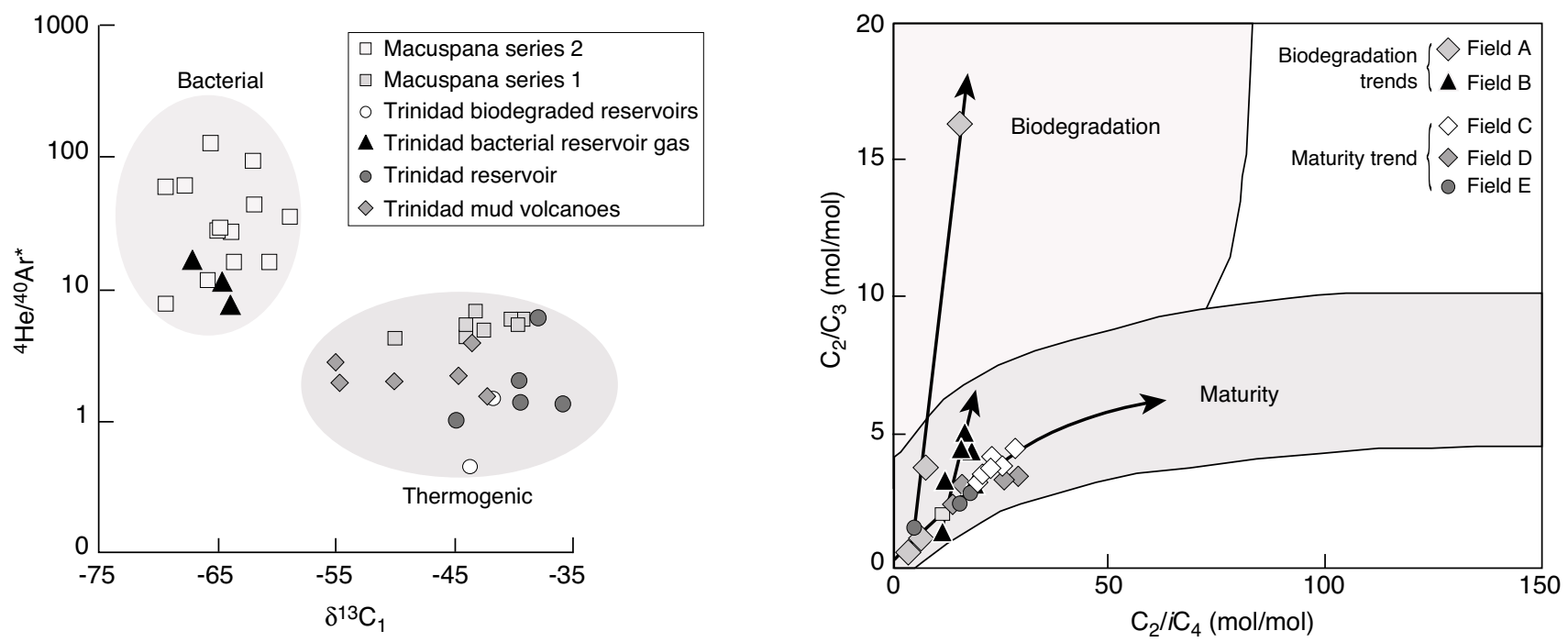

Figure 4

Distinction of thermogenic and bacterial origin of natural gas, combining the use of carbon isotopes and noble gases. The gases presented in this diagram have unambiguous bacterial or thermogenic origins, without any mixing or post-genetic fractionation. Bacterial gases have light carbon isotopic signatures, and high apparent production ratios ${ }^{4} \mathrm{He} /{ }^{40} \mathrm{Ar} *$ compared to the average crustal value. Data from Prinzhofer et al. (2000c) and unpublished data.

Figure 5

Diagram $\mathrm{C}_{2} / \mathrm{C}_{3}$ versus $\mathrm{C}_{2} / i \mathrm{C}_{4}$ (Prinzhofer et al., 2000b), distinguishing a maturity trend from a biodegradation trend. Some natural gas examples are shown exhibiting both processes. Field A, gases have a lower maturity than field B, both exhibiting a trend of biodegradation respectively.

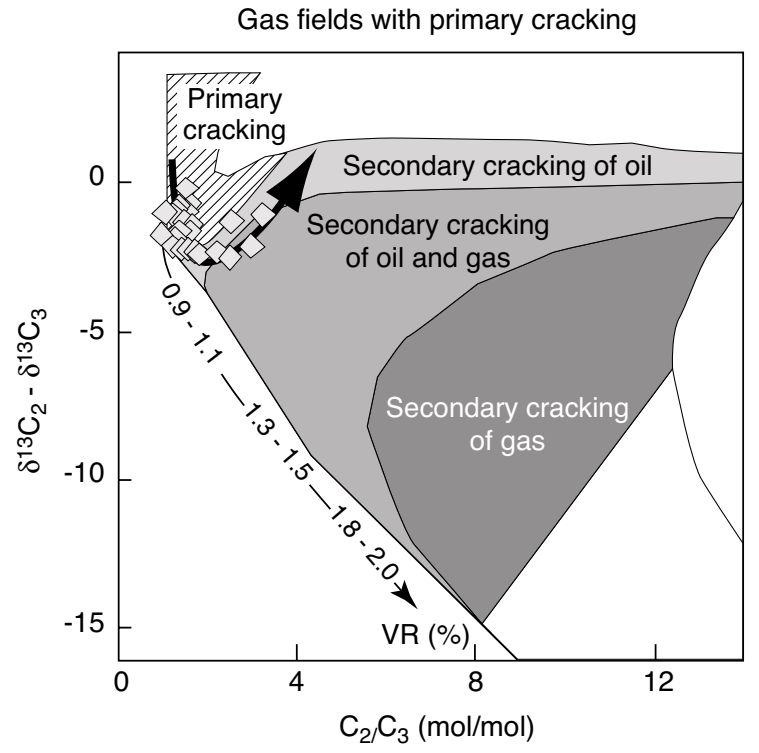

Ceara Basin

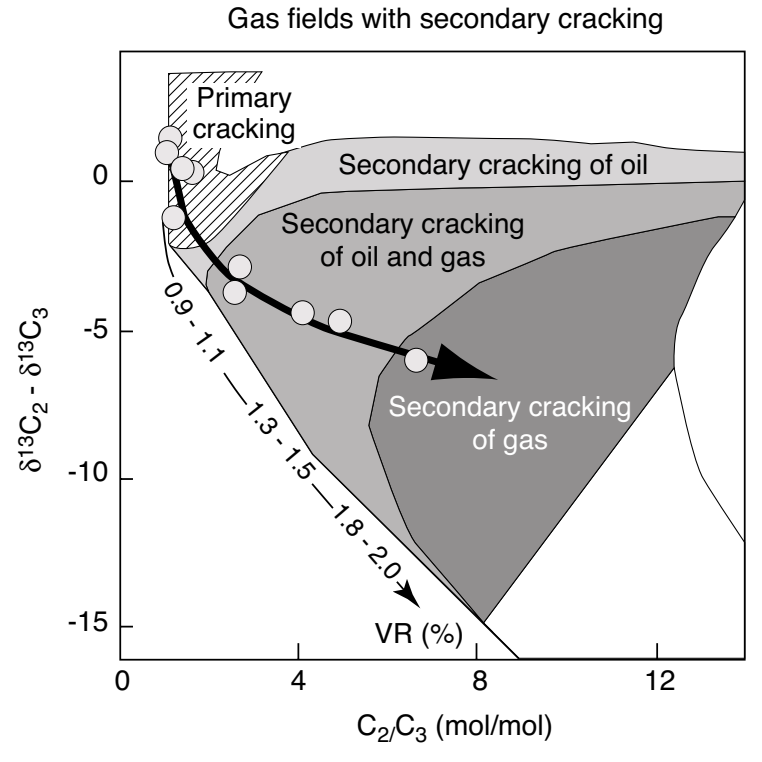

Thailand

Figure 6

$\delta^{13} \mathrm{C}_{2}-\delta^{13} \mathrm{C}_{3}$ versus $\mathrm{C}_{2} / \mathrm{C}_{3}$ diagram (Lorant et al., 1998), with two examples of gas series from the Ceara Basin, Brazil (Prinzhofer et al., $2000 \mathrm{~b}$ ) and from Thailand. The first case presents a trend of maturity of an open system during the primary cracking of kerogen, the second case presents a wider range of maturity in a more closed system, ranging from the primary cracking to secondary cracking of oil and gas. 
chemical and isotopic signatures of the $\mathrm{C}_{2}-\mathrm{C}_{4}$ fraction of the gases (Lorant et al., 1998; Prinzhofer et al., 2000a; Prinzhofer et al., 2000b). Two main diagrams were established, the first one $\left(\mathrm{C}_{2} / \mathrm{C}_{3}\right.$ versus $\left.\mathrm{C}_{2} / i \mathrm{C}_{4}\right)$ allowing to distinguish any gas biodegradation versus a maturity trend. Its principle is that for a maturity trend, $i \mathrm{C}_{4}$ proportions decrease more rapidly than $\mathrm{C}_{3}$ proportions. On the contrary, during a biodegradation process, propane (and $n \mathrm{C}_{4}$ ) are more efficiently altered than $i \mathrm{C}_{4}$. Figure 5 gives some examples of gas signatures plotted in this diagram. It is seen that for a given basin, gases from some reservoirs exhibit a trend of maturity, whereas for some other hydrocarbon accumulations, a trend of biodegradation may be defined.

An other diagram using both the chemical and isotopic signatures of ethane and propane was developed in order to better characterize the maturity of the gas. For correctly interpreting data, an other important parameter to take into account is the degree of openness of the system, as the maturity trends depend drastically on the retention of the hydrocarbons in the generation area or not. Figure 6 presents gas data from two different basins, one corresponding to gas generated during the primary cracking of the kerogen, the other one where a large proportion of the gases comes from the secondary cracking of the liquid hydrocarbons. This efficiency of accumulation is primordial when characterizing the composition of accumulated fluids. Indeed, as shown in Figure 7, for the same source rock and for the same maturation history, a reservoir accumulating all the produced hydrocarbons will be filled with oil and gas, whereas a reservoir accumulating only in the last part of the generated hydrocarbons may be filled only with dry gas.

\section{GAS AS A TRACER OF MIGRATION: STABLE ISOTOPES VERSUS NOBLE GAS SIGNATURES}

Segregation during the migration of natural gas may be monitored through the carbon isotopes of methane (Prinzhofer and Pernaton, 1997; Prinzhofer et al., 2000a). As presented earlier, the carbon isotopes of methane fractionate during migration with an enrichment in the light isotope ${ }^{12} \mathrm{C}$. This observation obscures the diagnostic on the origins of gases, but may help in the same time the reconstruction of the directions of migration. However, as said before, these signatures are strongly dependent on the kind of genesis of the gas (bacterial versus thermogenic), on the isotopic signature of the source and of its maturity, complexing the fractionation due to gas migration through porous rocks.

On the contrary, because of their chemical inertia, isotopic and chemical ratios of noble gases are fractionated only by physical processes, i.e. in this case the interaction between fluids and fractionation during diffusion. The ratios between two fossil isotopes of noble gases (of two different chemical species) are controlled by the atmospheric ratio, the relative

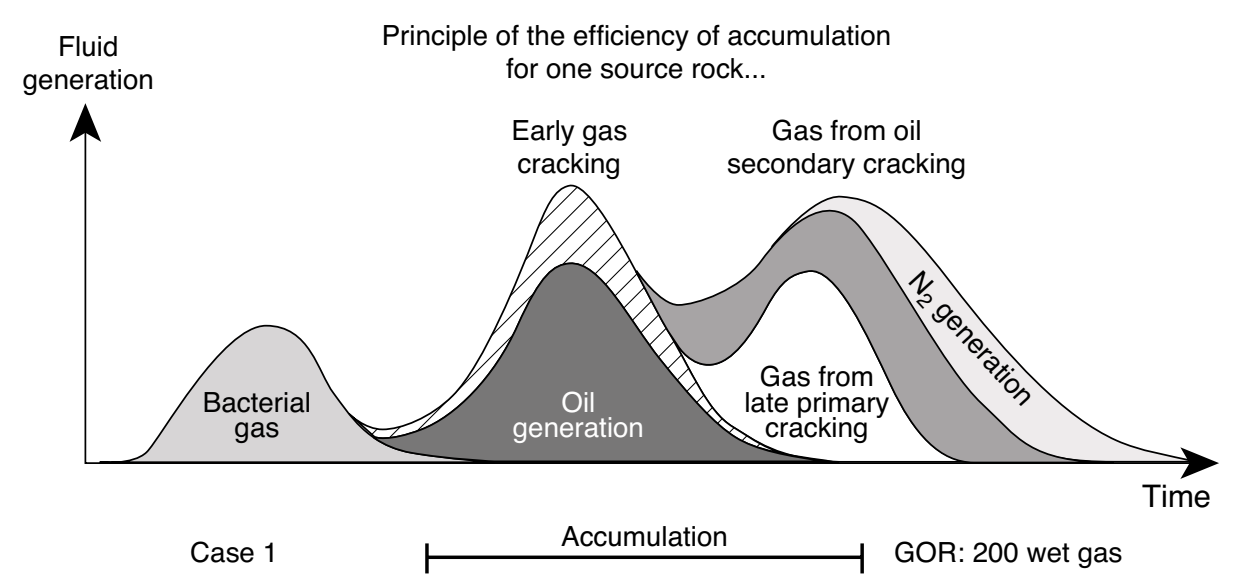

Case 2

Accumulation GOR: 3000 dry gas

Case 3

Accumulation

Dry gas

Figure 7

General scheme of hydrocarbon and $\mathrm{N}_{2}$ generation from organic matter. The range of accumulation time has a direct influence on the composition of reservoired hydrocarbons, a late accumulation being enriched in gas as compared to a complete accumulation. For overmature source rocks, a late accumulation may lead to a gas highly enriched in nitrogen. 

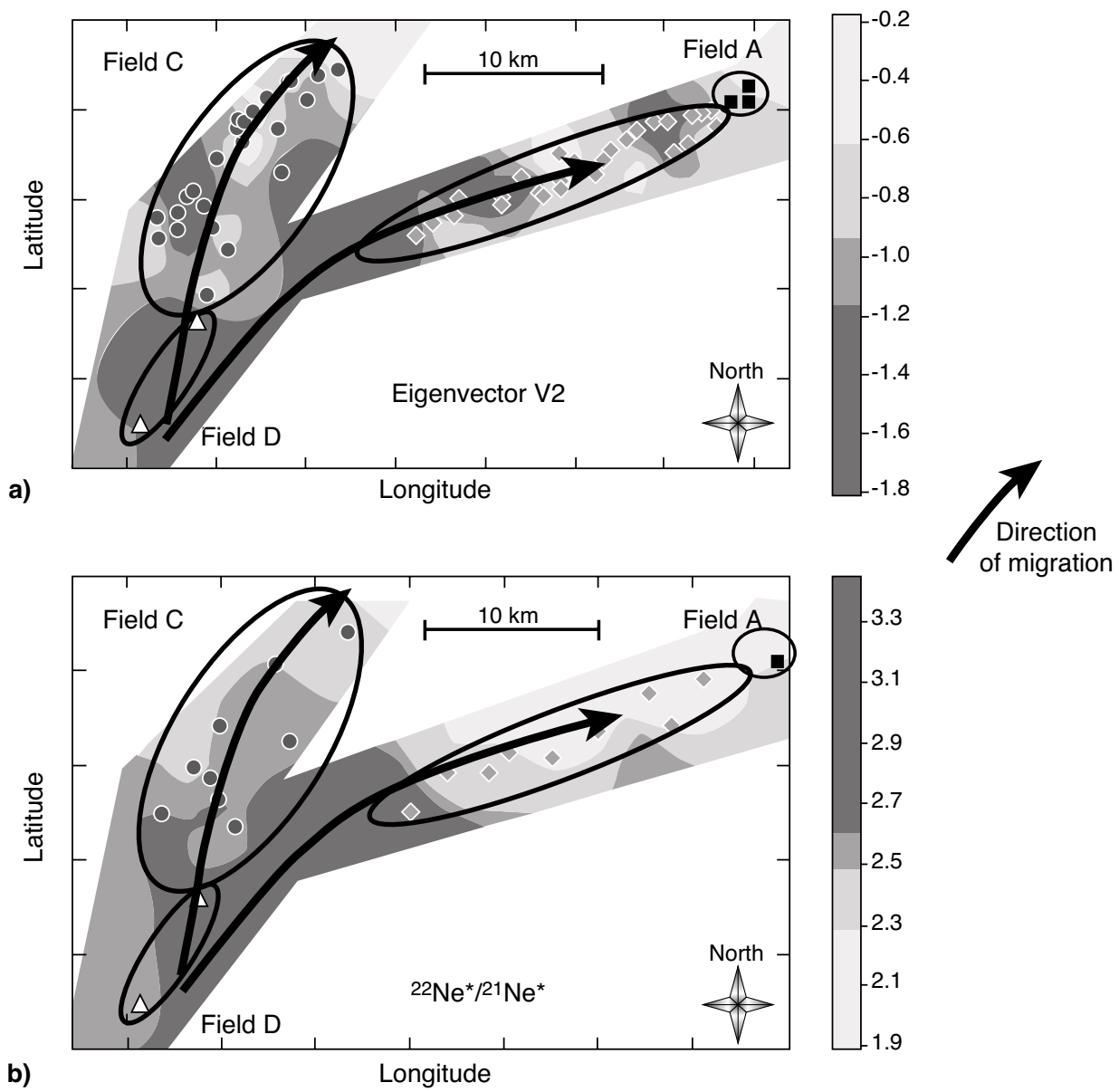

Migration maps in a series of reservoirs of a Brazilian basin (Prinzhofer et al., 2000d), using (a) the PCA method based on the proportion and the carbon isotopic ratios of hydrocarbons (Prinzhofer et al., 2000a) and (b) the isotopic ratios of the nucleogenic part of ${ }^{21} \mathrm{Ne}$ and ${ }^{22} \mathrm{Ne}$ (Prinzhofer et al., 2000d). Both tracers indicate a direction of migration from the southwest to the northeast.

solubilities of noble gas in water in the aquifer recharges, and to fractionation processes due to migration in sedimentary rocks. For radiogenic and nucleogenic isotopes, their relative ratios are controlled by the average crustal production ratio and by the transfer function from the rocks to the hydrocarbons. It is then possible to characterize the direction of migration with the same physical principle, which implies that a light molecule moves faster than a heavy one. The fractionation may occur for both fossil and radiogenic isotopes, indicating a late fractionation. On the contrary, if only the fossil isotopes are fractionated, this means that the differentiation occurred before the integration of radiogenic isotopes into the hydrocarbons. In Figure 8 are presented two maps of fractionation due to migration. Figure 8a represents a fractionation linked mainly to the carbon isotopic ratios of methane, quantified with the second eigenvector of a PCA, mainly linked with the carbon isotope composition of methane (Prinzhofer et al., 2000a). An enrichment in ${ }^{12} \mathrm{C}$ from the southwest to the northeast indicates that the pod of generation is likely located southwest of the reservoirs. When comparing such results with a ratio of two nucleogenic isotopes ${ }^{21} \mathrm{Ne}^{*}$ and ${ }^{22} \mathrm{Ne}^{*}$ (Fig. $8 b$ ), the same relative enrichment in light isotopes is visible to the northeast of the studied area, confirming the direction of accumulation of hydrocarbons.

In other cases, mixture with bacterial methane will obscure the fractionation of carbon isotopes due to migration, while noble gases will not be affected by this hydrocarbon mixing process, and will give a consistent direction of migration. Figure 9 represents in the basin of Macuspana (Mexico) the fractionation of ratios of fossil and radiogenic isotopes respectively (Prinzhofer et al., 2000c). A consistent direction of migration from south to north is visible, although the values of $\delta^{13} \mathrm{C}$ of methane do not give a clear clue about migration because of an important mixing between a bacterial and a thermogenic end-member (Prinzhofer et al., 2000c). Figure $9 \mathrm{c}$ and $9 \mathrm{~d}$ show that the projection of the iso- $\delta^{13} \mathrm{C}$ of methane and ethane are similar, although some shift does 


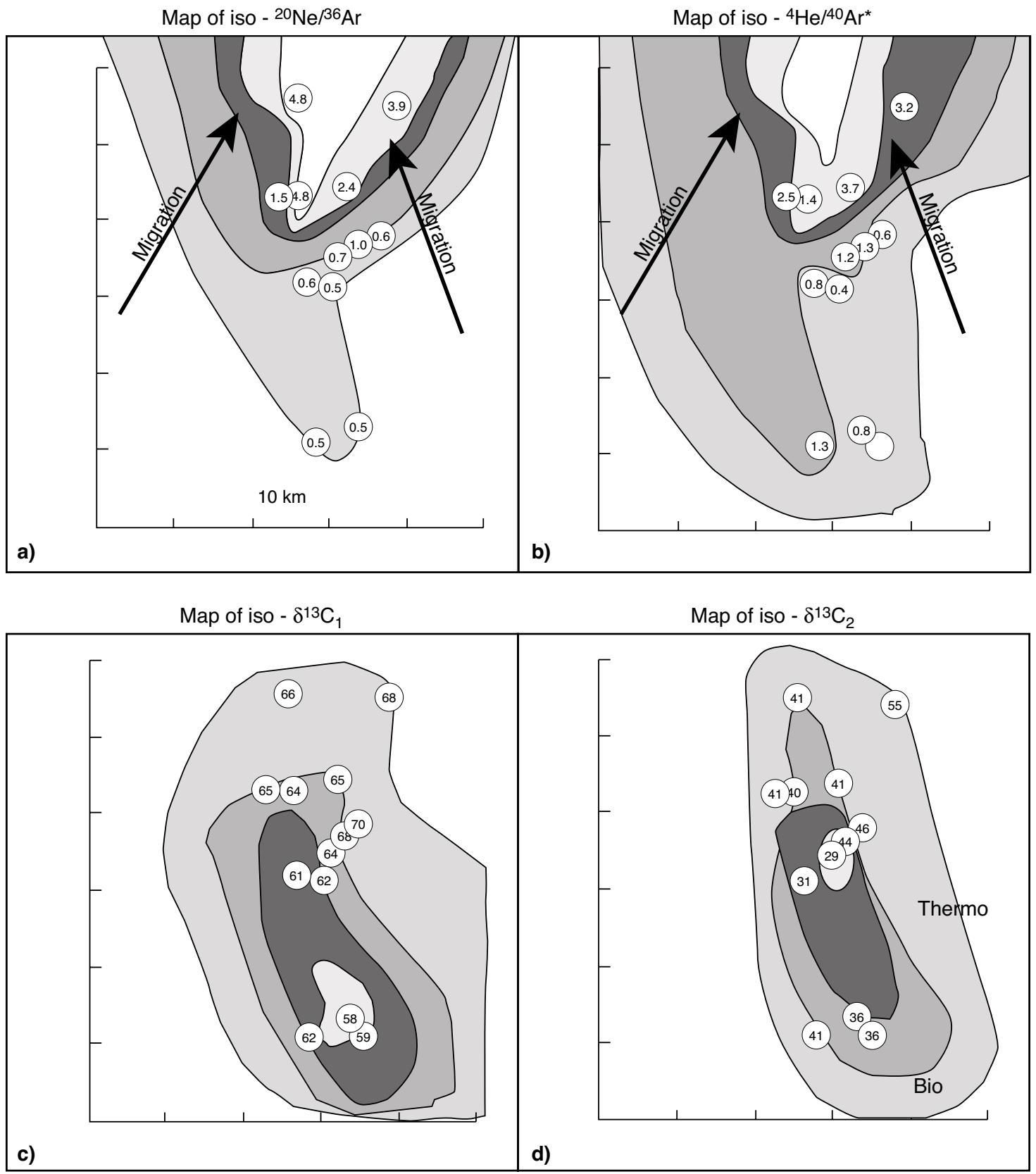

Figure 9

Maps of several gas geochemical parameters in the Macuspana Basin, Mexico (Prinzhofer et al., 2000c).

a) map of the iso-values of the ratio of two fossil noble gas isotopes ${ }^{20} \mathrm{Ne} /{ }^{36} \mathrm{Ar}$.

b) map of the iso-values of the ratio of two radiogenic noble gas isotopes ${ }^{4} \mathrm{He} /{ }^{40} \mathrm{Ar} *$.

c) map of the iso-values of the carbon isotopic ratio of methane.

d) map of the iso-values of the carbon isotopic ratio of ethane.

The four maps indicate a consistent direction of migration from the south to the north. 
persist between the positions of the less negative $\delta^{13} \mathrm{C}$. These images were interpreted (Prinzhofer et al., 2000c) as due to a mixing between a bacterial gas impregnated with a small amount of thermogenic gas, whose proportion increases from the edge to the center of the studied area. The shift between the two maximum of $\delta^{13} \mathrm{C}$ between methane and ethane is further interpreted as due to a higher fractionation of methane because of longer migration. As the heaviest methane is shifted south of the studied area, this would indicate a heavier residue of leakage located south, i.e. a migration from the south to the north, in perfect agreement with the fractionations of the noble gas isotopes. The combined approach of $\delta^{13} \mathrm{C}$ and noble gas demonstrates the importance of gain of information from all these gaseous species.

\section{NEW CHALLENGES: RESIDENCE TIME OF HYDROCARBONS, QUANTIFICATION OF LEAKAGE OUT OF THE RESERVOIRS}

As was assessed in the introduction, noble gases $(\mathrm{He}, \mathrm{Ne}, \mathrm{Ar}$, $\mathrm{Kr}, \mathrm{Xe}$ ) contain isotopes generated through natural nuclear reactions occurring in the minerals. Some isotopes are radiogenic, i.e. generated by the radioactive decay of a radioactive isotope. The others are called nucleogenic, and their generation occurs through nuclear reactions as $(\alpha, n)$ or $(\mathrm{n}, \alpha)$ on nuclei of $\mathrm{Li}, \mathrm{Mg}, \mathrm{F}, \mathrm{O}$, etc. The absolute amount of generated stable radiogenic and nucleogenic isotopes is increasing linearly with time, for compatible time ranges involved in petroleum systems (several hundred of million years). For a given radiogenic or nucleogenic isotope, a part of it comes from generation occurring before the history of the petroleum system, and presents an atmospheric proportion when compared to the same isotopes of the same elements. This makes possible the distinction, for a given concentration of a so-called radiogenic or nucleogenic isotope, of a "fossil" part and of a "radiogenic" part, if an other isotope of the same element is only fossil. Taking the example of argon, as ${ }^{36} \mathrm{Ar}$ is only fossil, it is possible to calculate the concentration of fossil ${ }^{40} \mathrm{Ar}\left({ }^{40} \mathrm{Ar}_{\mathrm{o}}\right)$, knowing the atmospheric ratio ${ }^{40} \mathrm{Ar} /{ }^{36} \mathrm{Ar}$ equal to 295.5:

$$
{ }^{40} \mathrm{Ar}_{\mathrm{o}}=295.5 \cdot{ }^{36} \mathrm{Ar}
$$

and the concentration of the radiogenic ${ }^{40} \mathrm{Ar}\left({ }^{40} \mathrm{Ar} *\right)$ :

$$
{ }^{40} \mathrm{Ar} *={ }^{40} \mathrm{Ar}-40 \mathrm{Ar}_{\mathrm{o}}={ }^{40} \mathrm{Ar}\left(1-295.5 \cdot{ }^{36} \mathrm{Ar}\right)
$$

As both isotopes, fossil and radiogenic/nucleogenic, are rigorously the same physical element (i.e. will not suffer any physical or chemical fractionation as they are physically undistinguishable), the ratio of radiogenic (or nucleogenic) over fossil concentration is linearly linked to the residence time of the hydrocarbon fluid. The coefficient of proportionality is not constrained yet, but for a given geological situation, as for example, several fields that produce with the same geological interval and with hydrocarbons originating from the same source rocks, it is possible to quantify in a relative way the residence times of hydrocarbon accumulations. Figure 10a shows that for the same example than illustrated and discussed on Figure 8, the gases from the two fields $\mathrm{A}$ and $\mathrm{B}$ have similar ratios in a diagram ${ }^{40} \mathrm{Ar}^{*}$ versus ${ }^{40} \mathrm{Ar}_{\mathrm{o}}$, and their different values define a straight line passing through the origin. The gases from fields C and D define an other straight line with a slope presenting a larger value. The ratio between the two slopes equals 1.34. Looking at other nucleogenic isotopes as ${ }^{21} \mathrm{Ne}$ and ${ }^{22} \mathrm{Ne}$ for the same gas wells, the same kind of diagram is visible, with ratios between the two linear correlation trends of 1.30 and 1.44 respectively (Figs $10 \mathrm{~b}$ and $\mathrm{c}$ ). The good consistency between these three values of slope ratios confirms the quantitative estimate of the relative residence time of hydrocarbons in these reservoirs, the hydrocarbons of reservoirs $\mathrm{C}$ and $\mathrm{D}$ having a residence time approximately $35 \%$ longer than in the reservoirs $\mathrm{A}$ and $\mathrm{B}$.

Another new powerful application of noble gas isotopes consists on using them as inert tracers of leakage from the reservoirs through caprocks or aquifers. In fact, it is common sense to say that helium leaks much more easily than other gases because of its size (except hydrogen). As the noble gas family corresponds to a series of gas molecules from helium to xenon with increasing size, the latest being a large molecule which does not migrates easily, it is possible to trace a leakage phenomenon looking either at concentrations of different noble gas compounds, or at ratios between two noble gas compounds of different size, the smaller moving out more rapidly than the larger. An increase of a "leaking" process should result in a decrease of the helium concentrations, and an increase of the ratios (heavy compound/light compound). Figure 11 shows for the same four fields of Figures 8 and 10, some correlation diagrams, plotting a ratio of two fossil noble gas isotopes versus the concentration of ${ }^{4} \mathrm{He}$. As the concentrations of ${ }^{4} \mathrm{He}$ decrease, all the ratios heavy/light compounds increase. The two trends for each diagram correspond to the two families of fields, A-B and C-D respectively. It has been noticed that the absolute concentrations of argon are relatively constant in these families, whereas the concentrations of helium and neon are decreasing versus the importance of accumulation leakage, while the concentrations of krypton and xenon are increasing. This indicates that the leakage factor for the hydrocarbons is in the same order than the leakage of argon, as the argon concentrations - constant-correspond to the ratios of the absolute amount of argon over the whole gas amount. It is then possible to quantify the proportions of hydrocarbons lost through leakage for each gas sample, fitting the curves of Figure 11 with different diffusivities for helium, neon, argon, krypton and xenon (for the noble gas ratios), and using the same diffusivity for argon and for hydrocarbons 

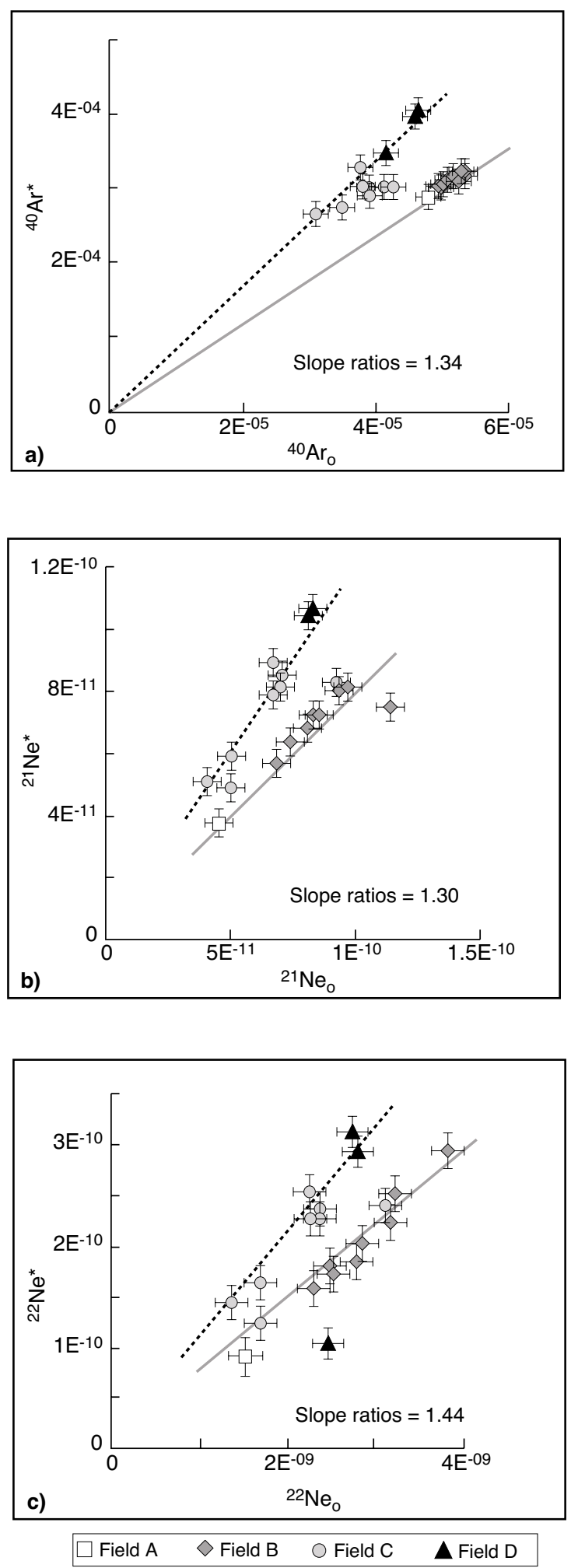

Figure 10

Correlation between the fossil and the radiogenic/nucleogenic part of the isotopes ${ }^{40} \mathrm{Ar},{ }^{21} \mathrm{Ne}$ and ${ }^{22} \mathrm{Ne}$ for the four fields of Figure 8 . The ratios $X^{*} / X_{0}$ are proportional to the residence time of the hydrocarbons.
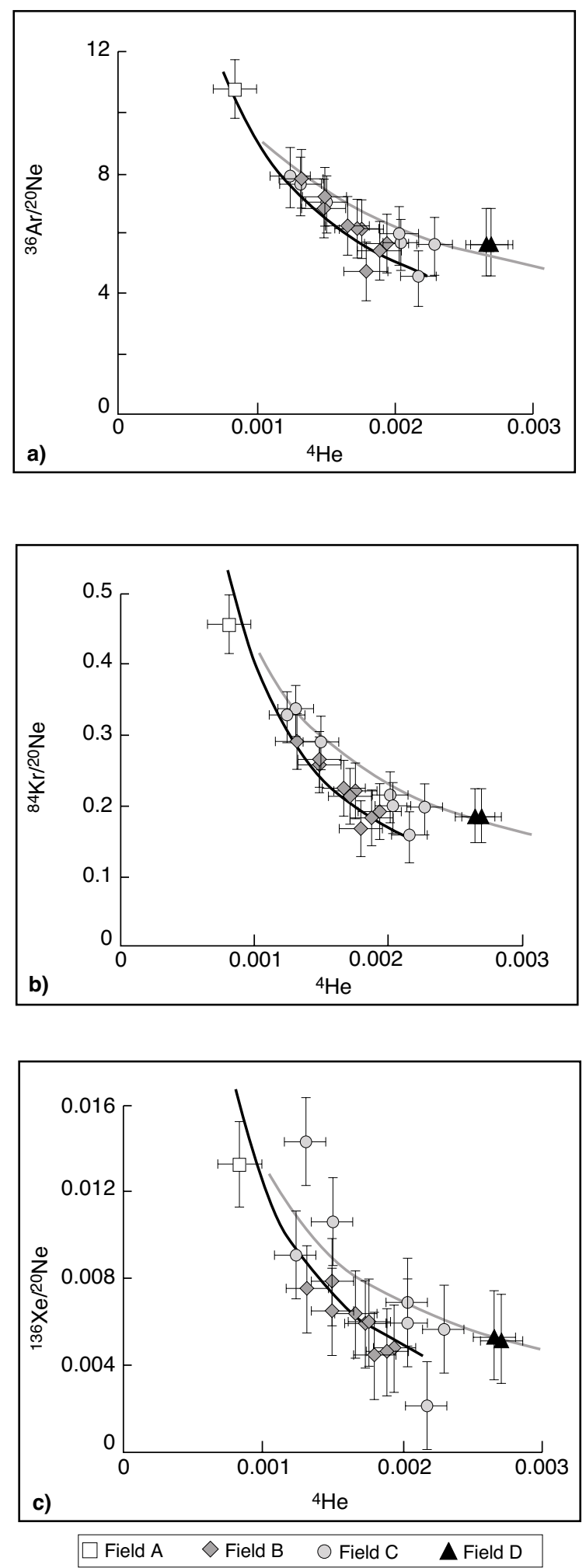

Figure 11

Correlations between the ratios of two fossil isotopes of noble gases and the concentrations of the radiogenic ${ }^{4} \mathrm{He}$ for the four fields from Figure 8. The observed trends are interpreted as due to leakage, which decreases the ${ }^{4} \mathrm{He}$ concentrations and increases the ratios heavy/light isotopes. 
for the helium concentrations. The result of this calculation is presented in the map of Figure 12. The proportions of displaced hydrocarbons range between 16 and $80 \%$, and their repartition indicates that fields $\mathrm{B}$ and $\mathrm{D}$ exhibit smaller leakage than fields $\mathrm{A}$ and $\mathrm{C}$.

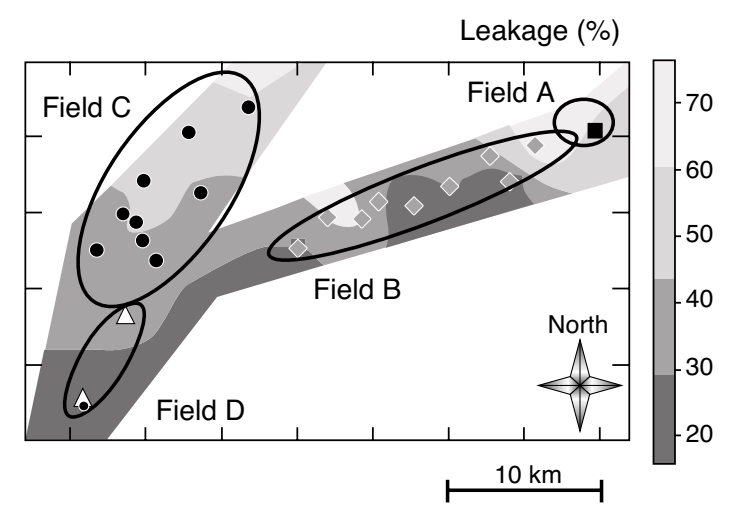

Figure 12

Map of the quantified proportion of hydrocarbons lost by leakage for the four fields of Figure 8.

\section{CONCLUSIONS}

From the recent developments in the geochemistry of natural gases, it appears that the use of carbon isotopes, extended to the whole range of gas molecules, gives an evaluation of the physico-chemical processes affecting hydrocarbons in sedimentary basins, including the source of the hydrocarbons, their genesis and their post-genetic history as their migration, accumulation, leakage and chemical alteration (bacterial and/or thermal). The recent development of noble gas isotopes tracing of these fluids gives a more accurate view of some of these processes, as the type of genesis and the secondary and tertiary migration of hydrocarbons. Some very new quantitative informations about the proportions of displaced hydrocarbons, and the residence time of hydrocarbons in reservoirs is still under development, giving to gas geochemistry new challenges for future applications outside oil and gas exploration, as for example the monitoring of hydrocarbon production, the monitoring of $\mathrm{CO}_{2}$ sequestration in aquifers or in depleted hydrocarbon reservoirs.

\section{REFERENCES}

Ballentine, C.J. and O'Nions, R.K. (1994) The Use of Natural $\mathrm{He}, \mathrm{Ne}$ and $\mathrm{Ar}$ Isotopes to Study Hydrocarbon-Related Fluid Provenance, Migration and Mass Balance in Sedimentary Basins. From Parnell J. (ed.) 1994, Geofluids: Origin, Migration and Evolution of Fluids in Sedimentary Basins. Geological Society, Special Publication, 78, 347-361.
Ballentine, C.J. and Sherwood-Lollar, B.S. (2002) Regional Groundwater Focusing of Nitrogen and Noble Gases into the Hufoton-Panhandle Giant Field, USA. Geochim. Cosmochim. Acta, 66, 14, 2483-2497.

Battani, A. (1999) Utilisation des gaz rares $\mathrm{He}$, Ne et Ar pour l'exploration pétrolière et gazière : exemple des accumulations du Pakistan et de Macuspana (Mexique). PhD, Paris University.

Battani, A., Sarda, Ph. and Prinzhofer, A. (2000) Geochemical Study of Pakistani Natural Gas Accumulations Combining Major Elements and Rare Gas Tracing. Earth and Planet. Sci. Lett., 181, 229-249.

Bernard, B.B., Brooks, J.M. and Sackett, W.M. (1977) A Geochemical Model for Characterization of Hydrocarbon Gas Sources in Marine Sediments. In Offshore Technology Conference, May 1977, OTC 2934, 435-438.

Bosch, A. and Mazor, E. (1988) Natural Gas Association with Water and Oil as Depicted by Atmospheric Noble Gases: Case Study from the Southeastern Mediterranean Coastal Plain. Earth Planet. Sci. Letters, 87, 338-346.

Charlou, J.L. and Donval, J.P. (1993) Hydrothermal Methane Venting between $12^{\circ} \mathrm{N}$ and $26^{\circ} \mathrm{N}$ along the Mid-Atlantic Ridge. Journal of Geophys. Research, 98, B6, 9625-9642.

Charlou, J.L., Fouquet, Y., Bougault, H., Donval, J.P., Étoubleau, J., Jean-Baptiste, Ph., Dapoigny, A., Appriou, P. and Rona, P.A. (1998) Intense $\mathrm{CH}_{4}$ Plumes Generated by Serpentinization of Ultramafic Rocks at the Intersection of the $15^{\circ} 20^{\prime} \mathrm{N}$ Fracture Zone and the Mid-Atlantic Ridge. Geochim. Cosmochim. Acta, 62, 13, 2323-2333.

Colombo, U., Gazzarrini, F., Gonfiantini, R., Kneuper, G., Teichmüller, M. and Teichmüller, R. (1970) Carbon Isotope Study on Methane from German Coal Deposits. Hobson, G.D., Speers, G.C. (Eds.), Advances in Organic Geochemistry, 1966, Pergamon Press, Oxford, 1-26.

Elliot, T., Ballentine, C.J., O'Nions, R.K. and Ricchiuto, T. (1993) Carbon, Helium, Neon and Argon Isotopes in a Po Basin (Northern Italy) Natural Gas Field. Chemical Geology, 106, 429440.

Faber, E., Stahl, W.J. and Whiticar, M.J. (1992) Distinction of Bacterial and Thermogenic Hydrocarbon Gases: Bacterial Gas, R. Vially (Ed.), 63-74.

Galimov, E.M. (1988) Sources and Mechanisms of Formation of Gaseous Hydrocarbons in Sedimentary Rocks. In Origins of Methane in the Earth, Chem. Geol. (Special Issue), Schoell, M. (Ed.), 71, 77-95.

Guo, Zhanqian, Wang, Xianbin and Liu Wenlong (1997) Reservoir-Forming of Abiotic Gas in Songliao Basin. Science in China, Series D, 40, 6, 621-626.

Lorant, F., Prinzhofer, A., Béhar, F. and Huc, A.Y. (1998) Isotopic $\left({ }^{13} \mathrm{C}\right)$ and Molecular Constraints on the Formation and the Accumulation of Thermogenic Hydrocarbon Gases. Chemical Geology, 147, 249-264.

Prinzhofer, A. and Huc, A.Y. (1995) Genetic and Post-Genetic Molecular and Isotopic Fractionations in Natural Gases, Chemical Geology, 126, 3-4, 281-290.

Prinzhofer, A. and Pernaton, E. (1997) Isotopically Light Methane in Natural Gases: Bacterial Imprint or Segregative Migration? Chemical Geology, 142, 193-200.

Prinzhofer, A., Mello, M.R. and Takaki, T. (2000a) Geochemical Characterization of Natural Gas: a Physical Multivariable Approach and its Applications in Maturity and Migration Estimates. AAPG Bull., 84, 8, 1152-1172.

Prinzhofer, A., Mello, M.R., Da Silva Freitas, L.C. and Takaki, T. (2000b) New Geochemical Characterization of Natural Gas and its Use in Oil and Gas Evaluation. In Petroleum systems of South 
Atlantic Margins, AAPG Memoir 73, M.R. Mello and B.J. Katz (Eds.), 107-119.

Prinzhofer, A., Guzman-Vega, M.A., Battani, A and Escudero, M. (2000c) Gas Geochemistry of the Macuspana Basin, Mexico: Thermogenic Accumulations in Sediments Impregnated by Bacterial Gas. Marine and Petroleum Geology, 17, 1029-1040.

Prinzhofer, A., Vaz Dos Santos Neto, E., Magnier, C., Takaki, T. and Mello, M.R. (2000d) Geochemical Signatures of Gas and Oils in an Amazonian Accumulation. A dynamic Reconstruction of Hydrocarbon Filling and Leakage of a Reservoir. 7th ALAGO Meeting, 26-28 October 2000 (extended abstract).

Prinzhofer, A. (2001) Distinguishing Thermogenic and Biogenic Gases: the Past (Fingerprinting), the Present (Stable Isotopes and Geological Processes) and the Future (Noble Gas Isotope Signatures). AAPG Hedberg conference, Veracruz, Mexico, 4-7 Nov. 2001 (extended abstract).

Ricchiuto, T. and Schoell, M. (1988) Origin of Natural Gases in the Apulian Basin in South Italy: a Case history of Mixing of Gases of Deep and Shallow Origin. In Advances in Organic Geochemistry, Matavalli, L. Novelli, L. (Eds.), 311-318.
Schoell, M. (1980) The Hydrogen and Carbon Isotopic Composition of Methane from Natural Gases of Various Origins. Geochimica Cosmochimica Acta, 44, 649-661.

Schoell, M. (1983) Genetic Characterization of Natural Gases, AAPG Bulletin, 67, 12, 2225-2238.

Stahl, W.J. (1977) Carbon and Nitrogen Isotopes in Hydrocarbon Research and Exploration. Chemical Geology, 20, 121-149.

Szatmari, P. (1989) Petroleum Formation by Fisher-Tropsch Synthesis in Plate Tectonics. AAPG Bulletin, 73, 989-998.

Wang Xianbin, Li Chunyuan, Chen Jianfa, Xia Xinyu, Guo Zhanqian and Xie Hongsen (1997) On Abiogenic Natural Gas. Chinese Science Bulletin, 42, 16, 1327-1337.

Zartman, R.E., Wasserburg, G.J. and Reynolds, J.H. (1961) Helium, Argon and Carbon in some Natural Gases. Journ. of Geophys. Resarch, 66, 277-306.

Final manuscript received in February 2003 